\title{
The Response Surface Methodology for Depth-Dependent Chondrocyte Surface Area
}

\author{
Ekrem Çiçek $^{1 *}$ (]) \\ ${ }^{1}$ Department of Physics, Mehmet Akif Ersoy University, Burdur, Turkey
}

Geliş / Received: 17/11/2020, Kabul / Accepted: 24/06/2021

\begin{abstract}
Articular cartilage is a low-friction white connective tissue. The only cell type in articular cartilage are chondrocytes. They permit smooth articulation in cartilage. They have insufficient regenerative capacity. Response surface methodology is a very useful tool for the modelling of any processes using polynomials. This study investigated the depth-dependent chondrocyte surface area from bovine articular cartilage. Confocal microscope was utilized to image osteochondral explants. The response surface methodology was used to constitute the predictive regression model to guess chondrocyte area from confocal image of bovine articular cartilage. This methodology was employed to examine the relationships among input variables and response. The response was surface area of chondrocyte while the inputs were perimeter of chondrocyte and depth. The depth-dependent measured and calculated chondrocyte surface area was demonstrated. The response surface model was significant $(\mathrm{p}=0.001)$ and adequate for the prediction the chondrocyte surface area since $\mathrm{R} 2=0.81$. The chondrocyte surface area can be predicted with perimeter and depth by response surface methodology. The implementation of statistical experimental design techniques in image processing can reduce experimental runs and save experimental animals live.
\end{abstract}

Keywords: Cartilage, chondrocyte, response surface methodology

\section{Derinliğe Bağlı Kondrosit Yüzey Alanı İçin Cevap Yüzey Yöntemi}

$\ddot{O} z$

Eklem kıkırdağı, düşük sürtünmeli beyaz bir bağ dokusudur. Eklem kıkırdağındaki tek hücre tipi kondrositlerdir. Kıkırdakta düzgün eklemlenmeye izin verirler. Yetersiz rejeneratif kapasiteye sahiptirler. Cevap yüzey yöntemi, polinomları kullanarak herhangi bir işlemin modellenmesi için çok yararlı bir yöntemdir. $\mathrm{Bu}$ çalışmada, sığır eklem kıkırdağından kondrosit yüzey alanı derinliğe bağlı olarak incelenmiştir. Osteokondral eksplantların görüntülenmesi için konfokal mikroskop kullanılmıştır. Sığır eklem kıkırdağının konfokal görüntüsünden kondrosit alanını tahmin etmede öngörücü regresyon modelini oluşturmak için cevap yüzey yöntemi kullanıldı. Cevap yüzey yöntemi, girdi değişkenleri ve yanıt arasındaki ilişkileri incelemek için kullanılmıştır. Kondrosit yüzey alanı yanıt iken, kondrosit çevresi ve derinliği girdi değerleri olarak seçilmiştir. Derinliğe bağlı ölçülen ve hesaplanan kondrosit yüzey alanı gösterilmiştir. Cevap yüzey modeli anlamlı (p $=0.001$ ) ve R2 $=0.81$ olduğundan kondrosit yüzey alanının tahmini için yeterliydi. Cevap yüzey yöntemi kondrosit yüzey alanının tahmini için kullanılabilir. Görüntü işlemede istatistiksel deneysel tasarım tekniklerinin uygulanması, deneysel çalışmaları azaltabilir ve deney hayvanlarının hayatını kurtarabilir.

Anahtar Kelimeler: Kıkırdak, kondrosit, cevap yüzey yöntemi 


\section{Introduction}

Articular cartilage is a low-friction, smooth viscoelastic tissue that lines the articulating surfaces of synovial joints (Akkiraju and Nohe, 2015; Bajic et al., 2020). It distributes loads across the diarthrodial joints. It is almost entirely composed of the extracellular matrix. Chondrocytes are small population of specialized cells in the extracellular matrix. However, they are a key functional component in cartilage and providing mechanical support (Phull et al., 2016). Chondrocytes are responsible for sustaining and maintaining the cartilage. Chondrocytes are receiving more attention since articular cartilage has a low propensity for self-repair (Akkiraju and Nohe, 2015; Bajic et al., 2020). Chondrocyte death may trigger tissue degradation. Because, the remaining active cells may not be able to maintain the cartilage (Moo et al., 2013). The mature chondrocytes are about $13 \mathrm{~mm}$ diameter. They are playing a basic role in the maintenance of the extracellular matrix stabilization (Phull et al., 2016). A spectroscopic method was developed to determine cartilage thickness in-vivo in a previous study. It was reported that their method is able to estimate the cartilage thickness with an error of $12.8 \pm$ 9.5\% (Canpolat et al., 2017). The chondrocyte morphology determined by the pericellular matrix demonstrates a zonal specific dependency. Changes in chondrocyte morphology are dependent on the depth (Hall, 2019; Zhang et al., 2020).

Response surface methodology (RSM) is an empirical statistical approach to optimize many variables simultaneously to achieve optimal performance of the system (Akkiraju and Nohe, 2015; Ranade and Thiagarajan, 2017). RSM analyses the relationship between a set of experimental factors and response. RSM can effectively reduce experimental runs and can be used to evaluate the relative significance of experimental factors and their interactions. In the literature, in order to gain insight into the possible protective role of the structural elements surrounding chondrocytes, the role of the pericellular matrix and pericellular capsule were investigated in modelling chondrocyte mechanics. They reported that chondrocyte deformations depend on the cell's depth-dependent manner structural environment of the pericellular matrix (Han et al., 2011). The maximum amount of relevant information with a minimum expenditure of time is collected by design of experiment. The application of statistical experimental design techniques in image analysis can result in more information and reduced analysis time (Anupam et al., 2011; Annadurai et al., 2002).

The aim of this study was to investigate the depth-dependent chondrocyte surface area from bovine articular cartilage. The size of the chondrocyte was measured from the confocal image of articular cartilage. RSM was utilized to examine the relationships among input variables (perimeter of chondrocyte and depth) and response (surface area of chondrocyte).

\section{Materials and Method}

\subsection{Explant harvest}

Mature bovine knees with joint capsules were obtained from a local abattoir (Bud's Custom Meats, Riverside, IA). Osteochondral explants $(2.5 \mathrm{~cm}$ x $2.5 \mathrm{~cm})$ were carefully excised from the lateral tibial plateaus of the joints under sterile conditions. Then, they were placed immediately in Hanks balanced salt solution (HBSS). HBSS was supplemented with penicillin/streptomycin and amphotericin B. Explants were incubated in a culture medium during the whole study to maintain tissue viability (Ramakrishnan, 2011; Cicek and Arikanoglu, 2014; Goodwin, 2010; Martin et al., 2012). 


\subsection{Confocal imaging}

The explants were stained with dihydroethidium (DHE, Invitrogen) and calcein AM (Invitrogen) for $30 \mathrm{~min}$. The stained explants were scanned on a BioRad 1024 Confocal Microscope equipped with a Krypton/Argon laser (Biorad Laboratories Inc., Hercules, CA). Images of the osteochondral explants were performed with a $20 \times$ water immersion lens. The random sites close to the radial center were imaged from the surface to a depth of $\sim 200 \mu \mathrm{m}$ in $10 \mu \mathrm{m}$ intervals. $20 \times$ image stacks were acquired from randomly selected imaging sites. $20 \times$ image stacks were utilized for chondrocyte shapes analysis. More information regarding imaging conditions was described previously (Ramakrishnan, 2011; Cicek and Arikanoglu, 2014; Goodwin, 2010; Martin et al., 2012).

\subsection{Image Analysis}

The ImageJ version $1.53 \mathrm{~d}$ was used to analyze live cells from confocal image stacks. We measured the surface area of the chondrocyte, perimeter, long (major) and short axis (minor) inside cell, cell angle, circularity of the chondrocyte and aspect ratio. The size of chondrocyte was selected between 20 to $80 \mu \mathrm{m}^{2}$. The circularity of chondrocytes was among 0.01-1.00. ImageJ was just used for measurement. ImageJ version 1.53 for Windows was obtained from the NIH website (ImageJ, Rasband, W.S., U. S. National Institutes of Health, Bethesda, MD, http://rsb.info.nih.gov/ij/).

\subsection{Response Surface Methodology}

We utilized RSM for analysis and modeling. It is a useful statistical and mathematical technique as described previous studies in details (Cicek et al., 2008; Cicek et al., 2012; Khayet et al., 2008). The area (response) can be described which is influenced by controllable various input values in RSM model.

The general form of RSM can be demonstrated as below:

$$
\begin{aligned}
& \text { Area }=\beta_{0}+\beta_{1} x_{1}+\beta_{2} x_{2}+\beta_{11} x_{1}^{2}+\beta_{22} x_{2}^{2}+\beta_{12} x_{1} x_{2} \\
& \beta=\left[\beta_{0} \beta_{1} \beta_{2} \beta_{11} \beta_{22} \beta_{12}\right]^{\mathrm{T}} \\
& \beta=\left(X^{\mathrm{T}} \cdot X\right)^{-1} \cdot X^{\mathrm{T}} \cdot D F
\end{aligned}
$$

where: $\beta$ - present regression coefficients;

$\mathrm{X}$-input variables;

Area-response.

Chondrocyte surface area of bovine articular cartilage;

- regression model with actual variables:

$$
\begin{aligned}
& \text { Area }=-28+2.90 \text { Perimeter }-0.028 \text { Depth }-0.004 \text { Perimeter }^{2} \\
& -0.000091 \text { Depth }^{2}+0.0029 \text { PerimeterDepth }
\end{aligned}
$$


valid for the range: $21.97 \leq$ Perimeter $\leq 36.02(\mu \mathrm{m}) ;-20 \leq$ Depth $\leq-190(\mu \mathrm{m})$

The modeling details can be seen in previous studies (Cicek et al., 2008; Cicek et al., 2012; Khayet et al., 2008). All calculations were done by means of Minitab 19 software and Design Expert 12 trial version.

\section{Results}

Table 1 shows the experimental design for chondrocyte surface area. A total number of measured chondrocytes is 235 . The lowest $(21.97 \mu \mathrm{m})$ and highest $(36.02 \mu \mathrm{m})$ measured perimeter of chondrocyte were observed in $-30 \mu \mathrm{m}$ and $-190 \mu \mathrm{m}$ depth, respectively.

Table 1. Experimental design for chondrocyte surface area

\begin{tabular}{|c|c|c|c|c|c|}
\hline \multirow{3}{*}{$\begin{array}{c}\begin{array}{c}\text { Run } \\
\text { number }\end{array} \\
(\mathrm{N})\end{array}$} & \multirow{3}{*}{$\begin{array}{c}\begin{array}{c}\text { Cell } \\
\text { number }\end{array} \\
\text { (N) }\end{array}$} & \multicolumn{2}{|c|}{ Factors (Input values) } & \multirow{2}{*}{\multicolumn{2}{|c|}{$\begin{array}{c}\text { Response } \\
\text { Area }\left(\mu \mathrm{m}^{2}\right)\end{array}$}} \\
\hline & & \multirow{2}{*}{ Perimeter $(\mu \mathrm{m})$} & \multirow{2}{*}{ Depth $(\mu \mathrm{m})$} & & \\
\hline & & & & Measured & Predicted \\
\hline 1 & 3 & 26.48 & -20 & 42.04 & 45.74 \\
\hline 2 & 3 & 21.97 & -30 & 32.80 & 33.27 \\
\hline 3 & 3 & 32.80 & -40 & 61.08 & 60.22 \\
\hline 4 & 8 & 27.12 & -50 & 43.76 & 44.73 \\
\hline 5 & 6 & 29.00 & -60 & 54.05 & 48.69 \\
\hline 6 & 12 & 29.97 & -70 & 48.63 & 50.30 \\
\hline 7 & 19 & 29.66 & -80 & 50.60 & 48.62 \\
\hline 8 & 15 & 33.03 & -90 & 55.20 & 56.42 \\
\hline 9 & 15 & 30.69 & -100 & 53.39 & 49.52 \\
\hline 10 & 14 & 32.83 & -110 & 55.68 & 54.15 \\
\hline 11 & 16 & 34.28 & -120 & 53.19 & 57.00 \\
\hline 12 & 17 & 33.11 & -130 & 50.81 & 53.10 \\
\hline 13 & 18 & 31.77 & -140 & 54.13 & 48.78 \\
\hline 14 & 15 & 32.58 & -150 & 46.68 & 49.99 \\
\hline 15 & 39 & 32.40 & -160 & 48.14 & 48.63 \\
\hline 16 & 21 & 32.87 & -170 & 45.65 & 48.97 \\
\hline 17 & 10 & 36.02 & -190 & 57.63 & 55.31 \\
\hline
\end{tabular}




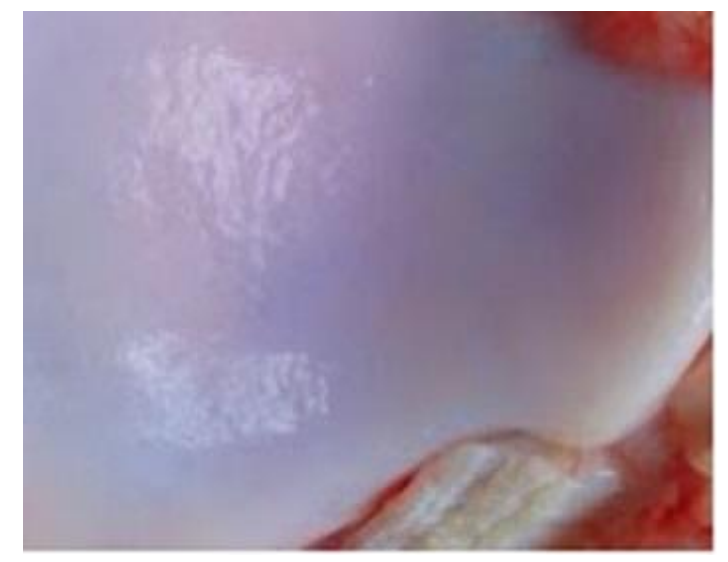

Figure 1. Articular cartilage tissue image from bovine knee

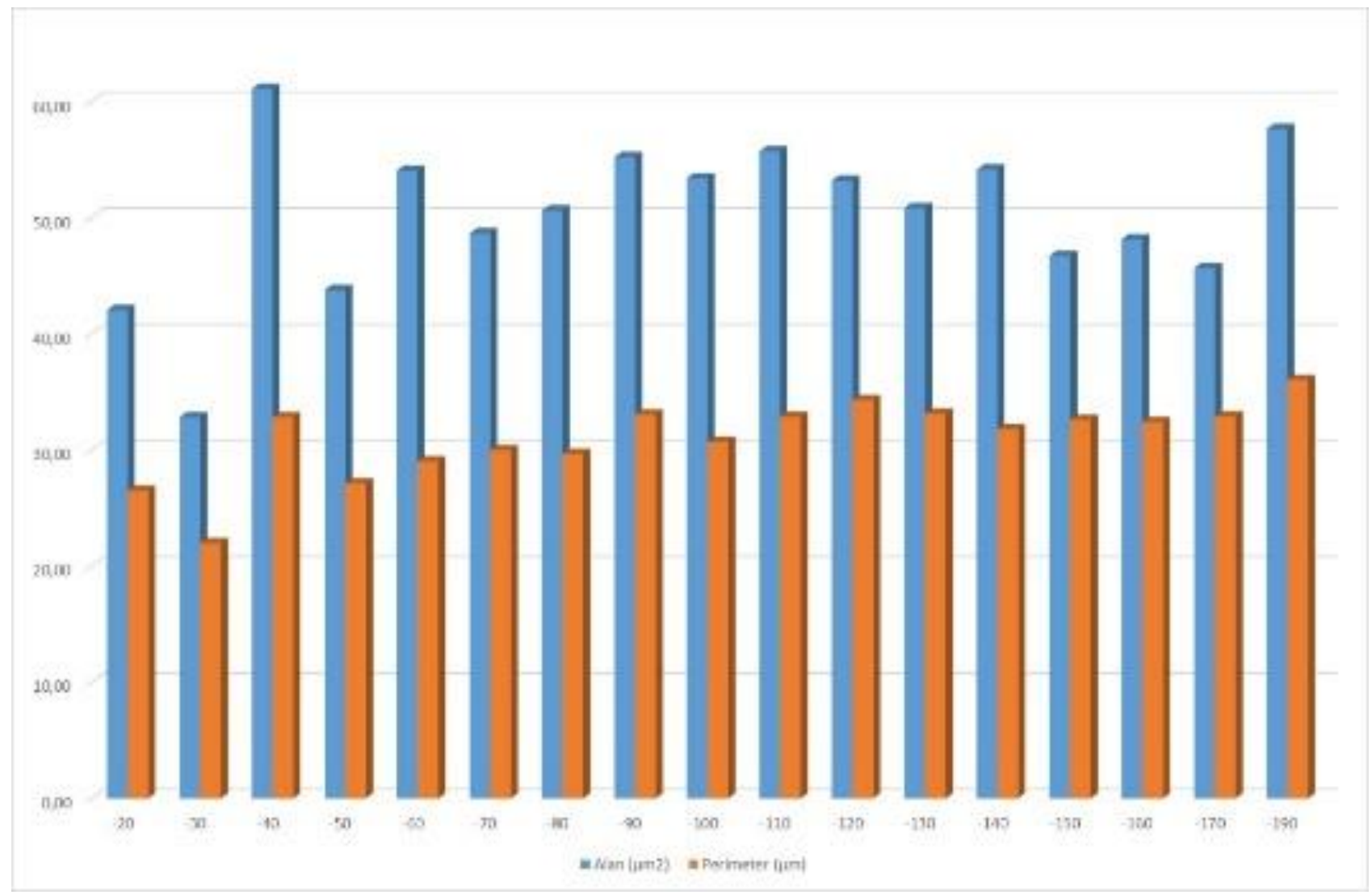

Figure 2. Measured perimeter and chondrocyte surface area depending on depth 


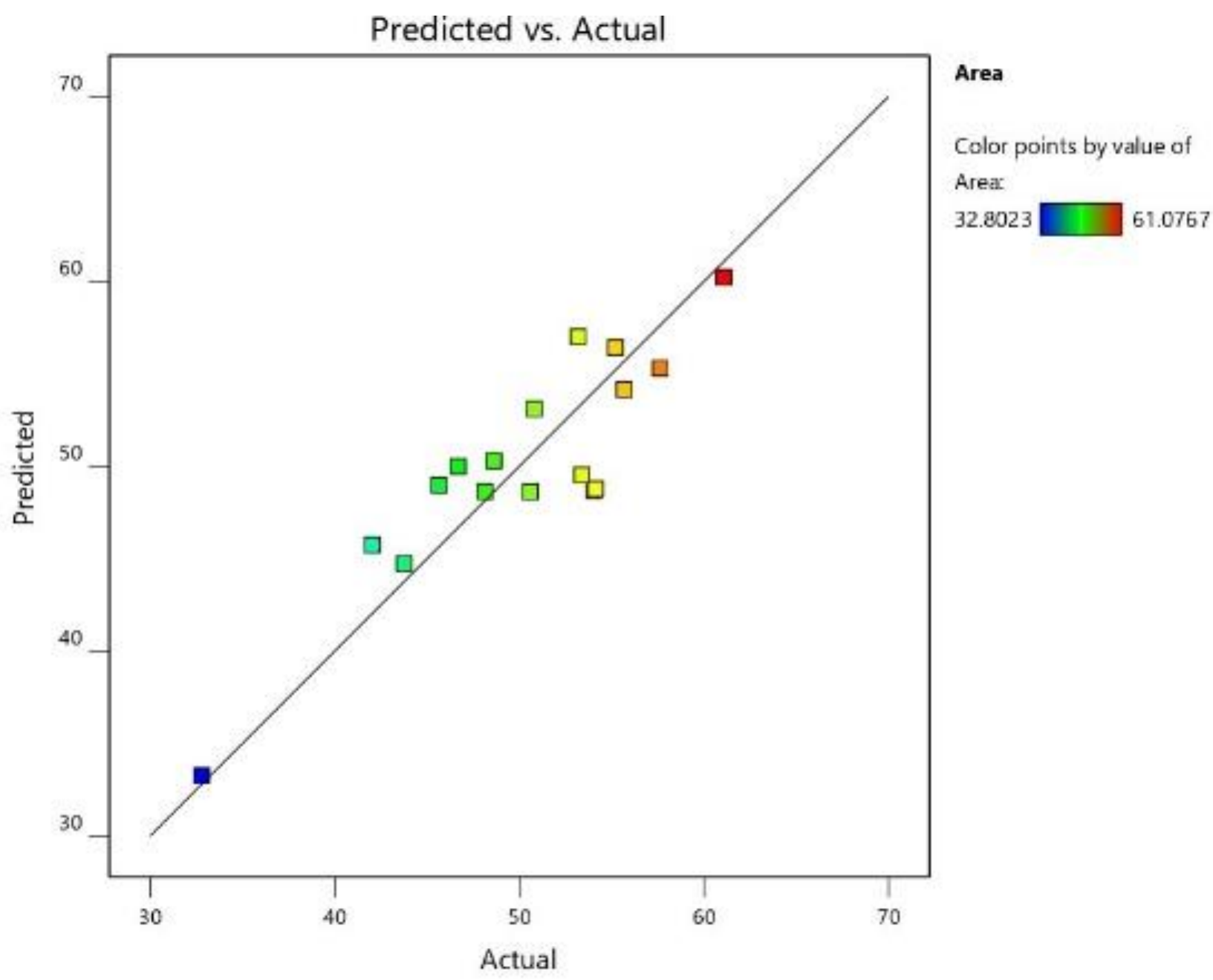

Figure 3. Predicted and actual chondrocyte surface area

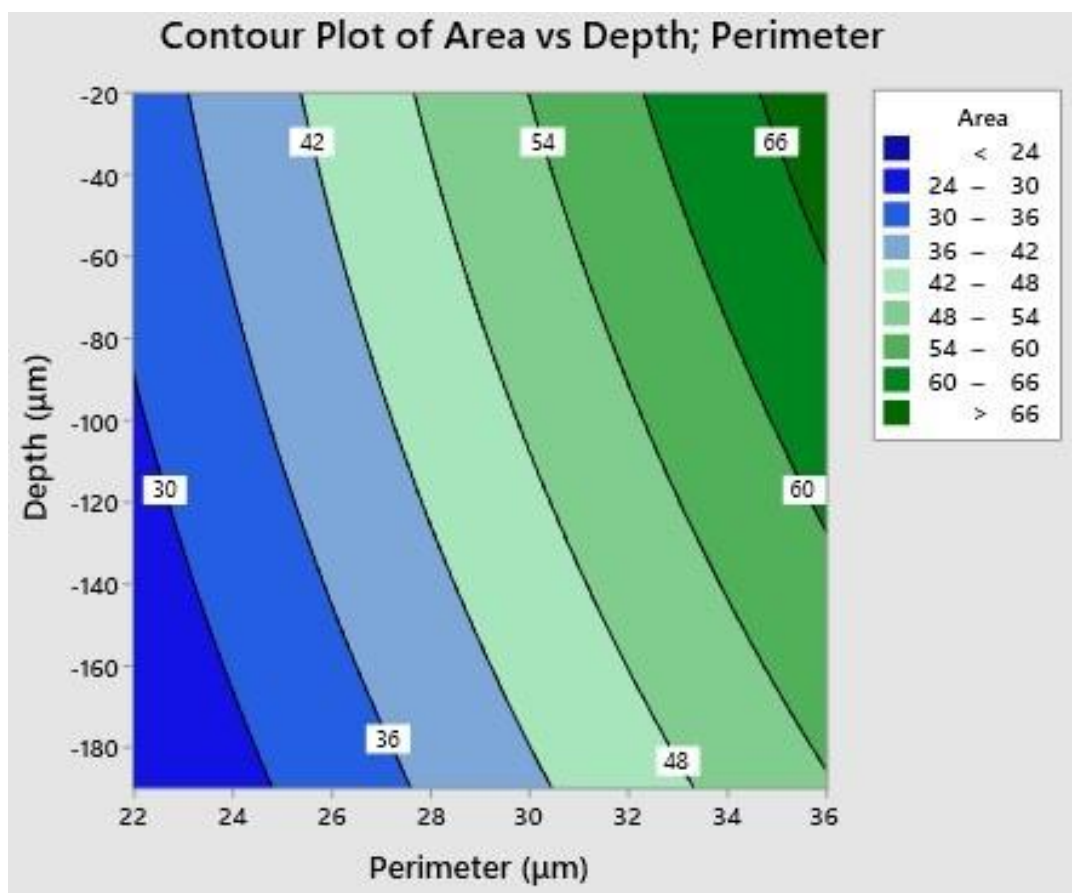

Figure 4. Contour plot for chondrocyte surface area depending on perimeter and depth 


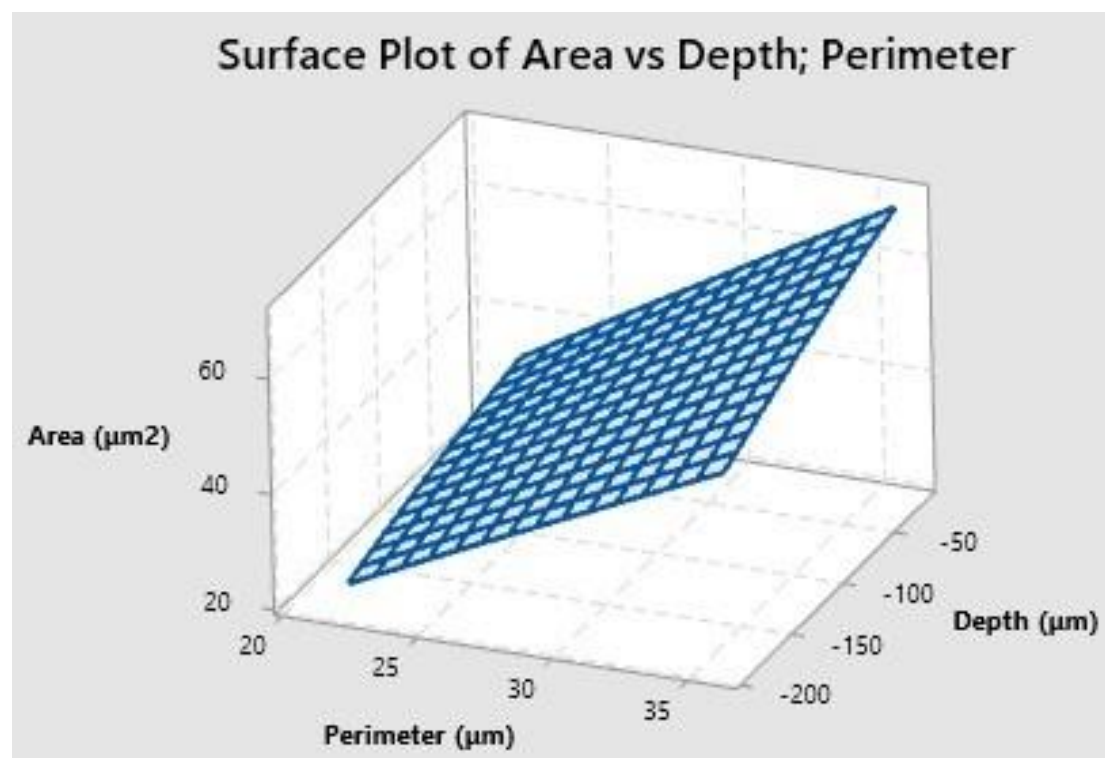

Figure 5. Response surface plot for chondrocyte surface area

Figure 1. shows articular cartilage tissue image from bovine knee. The images were taken from the center of the tissue (Figure 1). The depth-dependent measured values were seen for perimeter and chondrocyte surface area (Figure 2). As seen from the figure predicted values are very close to actual values (Figure 3 ).

It was seen the contour plot for chondrocyte surface area depending on perimeter and depth. The counter map demonstrates the chondrocyte surface area interconnection amid the perimeter of chondrocyte and depth (Figure 4). The increasing of perimeter of chondrocyte will give enhanced values of chondrocyte surface area (Figure 5). The surface area is increasing around the middle of the tissue depth (around $-100 \mu \mathrm{m}$ ). However, the highest surface area was measured at $-40 \mu \mathrm{m}$ depth as $61.08 \mu \mathrm{m} 2$.

The ANOVA was used to examine the accuracy of the calculated model. ANOVA test was chosen to find out if experiment results are significant. According to the results the model was compatible where the probability value was 0.001 . F value was 9.28 , it was pointed out that the experimental measured area obtained by changing the factor levels were statistically meaningful at the $81 \%$ confidence limit. $\mathrm{R}^{2}$ value should be close to 1 for a good statistical model. The mathematical model is adequate for the prediction the chondrocyte surface area since $\mathrm{R}^{2}=0.81>(0.75)$ (Le et al., 2010; Chauhan and Gupta, 2004).

\section{Discussion}

The chondrocytes are the only cells in articular cartilage. Their primary function is to provide structural support to articular cartilage that is essential in cartilage functions (Akkiraju and Nohe, 2015; Bajic et al., 2020). Cartilage has a depth-dependent composition. Chondrocytes' activity is related to their depth specific shape. Chondrocytes are responsible for the synthesis of type II collagen. Chondrocytes' shape dependent the zone in articular cartilage. In the superficial zone, chondrocytes shape is flat and aligned with the surface. The shape is spherical 
in the middle zone and elongated in the radial zone. It is important to determine the relationship among chondrocytes shape and their microenvironment for osteoarthritis. It is very difficult to evaluate chondrocyte behavior with experimental studies. So, computational models are necessary to study chondrocyte shape. The chondrocytes were modeled as spherical in all zones in many computational studies (Guo and Torzilli, 2016; Halloran et al., 2012; Guo et al., 2014).

In this study. we investigated the depth-dependent chondrocyte surface area. RSM was used to describe input variables (perimeter of chondrocyte and depth of chondrocyte) relationship with the response (chondrocyte surface area). The results showed that chondrocyte surface area can be predicted with perimeter and depth by response surface methodology. The probability value was 0.001 means that the model was compatible. The calculated results were statistically meaningful at the $81 \%$ confidence limit $(\mathrm{F}=9.28)$. In conclusion, this method can be used to determine other parameters of the chondrocyte as long (major) and short axis (minor) inside cell, cell angle, a circularity of the chondrocyte, and aspect ratio. Response surface methodology is a great prediction performance for chondrocyte surface area.

\section{References}

Akkiraju, H., Nohe, A. 2015. "Role of Chondrocytes in Cartilage Formation, Progression of Osteoarthritis and Cartilage Regeneration", Journal of Developmental Biology, 3(4), 177-192.

Annadurai, G., Juang, R. S., Lee, D. J. 2002. "Factorial Design Analysis for Adsorption of Dye on Activated Carbon Beads Incorporated with Calcium Alginate", Advances in Environmental Research, 6, 191-198.

Anupam, K., Dutta, S., Bhattacharjee, C., Datta, S. 2011. "Optimisation of adsorption efficiency for reactive red 198 removal from wastewater over TiO2 using response surface methodology”, The Canadian Journal of Chemical Engineering, 89, 1274-1280.

Bajic, A., Tarantino, R., Chiu, L. L. Y., Duever, T., Waldman, S. D. 2020. "Optimization of culture media to enhance the growth of tissue engineered cartilage", Biotechnology Progress, e3017, 1-12.

Canpolat, M., Gümüş, B., Özbey-Ünlü, Ö., Uslu, S., Nüzket, T., Üncü, Y. A., Söyüncü, Y., Turgut, Ç., Üstünel, İ. 2017. "Determination of cartilage thickness in-vivo using back reflection spectroscopy”, 21st National Biomedical Engineering Meeting (BIYOMUT), Istanbul, 1-4.

Chauhan, B., Gupta, R. 2004. "Application of statistical experimental design for optimization of alkaline protease production from Bacillus sp. RGR-14”, Process Biochemistry, 39(12), 2115-2122.

Cicek, E., Arikanoglu, A. 2014. "Morphological Variations of Chondrocytes in Bovine Articular Cartilage Using Confocal Laser Scanning Microscopy", Acta Physica Polonica A, 125(4), 898-901.

Cicek, E., Cojocaru, C., Zakrzewska-Trznadel, G., Harasimowicz, M., Miskiewicz, A. 2012. "Response surface methodology for the modeling of $85 \mathrm{Sr}$ adsorption on zeolite $3 \mathrm{~A}$ and pumice", Environmental Technology, 33(1), 51-59. 
Cicek, E., Cojocaru, C., Zakrzewska-Trznadel, G., Jaworska, A., Harasimowicz, M. 2008. "Response surface methodology for cobalt removal from aqua solutions using Isparta pumice and zeolite 4A adsorbents", Nukleonika, 53(S2), 121-128.

Goodwin, W., McCabe, D., Sauter, E., Reese, E., Walter, M., Buckwalter, J. A., Martin, J. A. 2010. "Rotenone prevents impact-induced chondrocyte death", Journal of Orthopaedic Research, 28(8), 1057-63.

Guo, H., Maher, S. A., Torzilli, P. A. 2014. "A biphasic multiscale study of the mechanical microenvironment of chondrocytes within articular cartilage under unconfined compression", The Journal of Biomechanics, 47, 2721-2729.

Guo, H., Torzilli, P. A. 2016. "Shape of chondrocytes within articular cartilage affects the solid but not the fluid microenvironment under unconfined compression", Acta Biomaterialia, 29, 170-179.

Hall, A. C. 2019. "The role of chondrocyte morphology and volume in controlling phenotypeimplications for osteoarthritis, cartilage repair, and cartilage engineering”, Current Rheumatology Reports, 21(8), 38.

Halloran, J. P., Sibole, S., van Donkelaar, C. C., van Turnhout, M. C., Oomens, C. W., Weiss, J. A., Guilak, F., Erdemir, A. 2012. "Multiscale mechanics of articular cartilage: potentials and challenges of coupling musculoskeletal, joint, and microscale computational models", Annals of Biomedical Engineering, 40(11), 2456-2474.

Han, S. K., Federico, S., Herzog, W. 2011. "A depth-dependent model of the pericellular microenvironment of chondrocytes in articular cartilage", Computer Methods in Biomechanics and Biomedical Engineering, 14(7), 657-664.

Khayet, M., Cojocaru, C., Zakrzewska-Trznadel, G. 2008. "Response surface modelling and optimization in pervaporation”, Journal of Membrane Science, 321, 272-283.

Le, M. H., Behera, S. K., Park, H. S. 2010. “Optimization of operational parameters for ethanol production from Korean food waste leachate", International Journal of Environmental Science and Technology, 7, 157-164.

Martin, J. A., Martini, A., Molinari, A., Morgan, W., Ramalingam, W., Buckwalter, J. A., McKinley, T. O. 2012. "Mitochondrial electron transport and glycolysis are coupled in articular cartilage", Osteoarthritis and Cartilage, 20(4), 323-329.

Moo, E. K., Amrein, M., Epstein, M., Duvall, M., Osman, N. A. A., Pingguan-Murphy, B., Herzog, W. 2013. "The Properties of Chondrocyte Membrane Reservoirs and Their Role in Impact-Induced Cell Death”, Biophysical Journal, 105(7), 1590-1600.

Phull, A. R., Eo, S. H., Abbas, Q., Ahmed, M., Kim, S. J. 2016. “Applications of ChondrocyteBased Cartilage Engineering: An Overview”, BioMed Research International, 1879837, 17. 
Ramakrishnan, P. S., Pedersen, D. R., Stroud, N. J., McCabe, D. J., Martin, J. A. 2011. "Repeated measurement of mechanical properties in viable osteochondral explants following a single blunt impact injury", Proceedings of the Institution of Mechanical Engineers H, 225(10), 993-1002.

Ranade, S. S., Thiagarajan, P. 2017. "Selection of a design for response surface", IOP Conf Ser: Materials Science and Engineering, 263(2), 022043.

Zhang, Q. Y., Bai, J. D., Wu, X. A., Liu, X. N., Zhang, M., Chen, W. Y. 2020. "Microniche geometry modulates the mechanical properties and calcium signaling of chondrocytes", Journal of Biomechanics, 104, 109729. 